\title{
Section dedicated to: Carl William Gottschalk
}

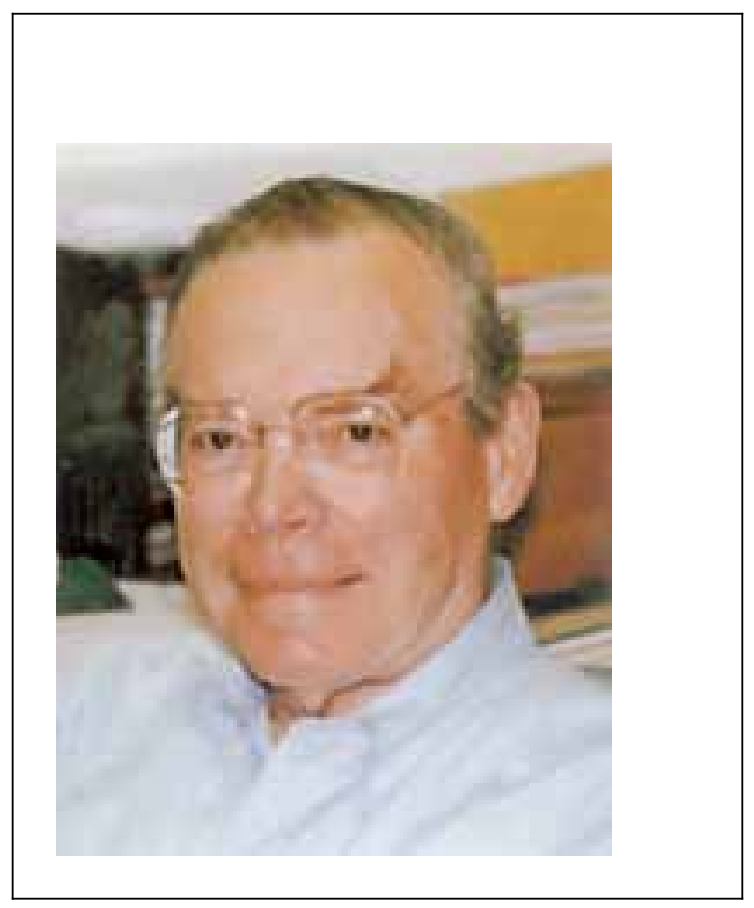

1922-1997 